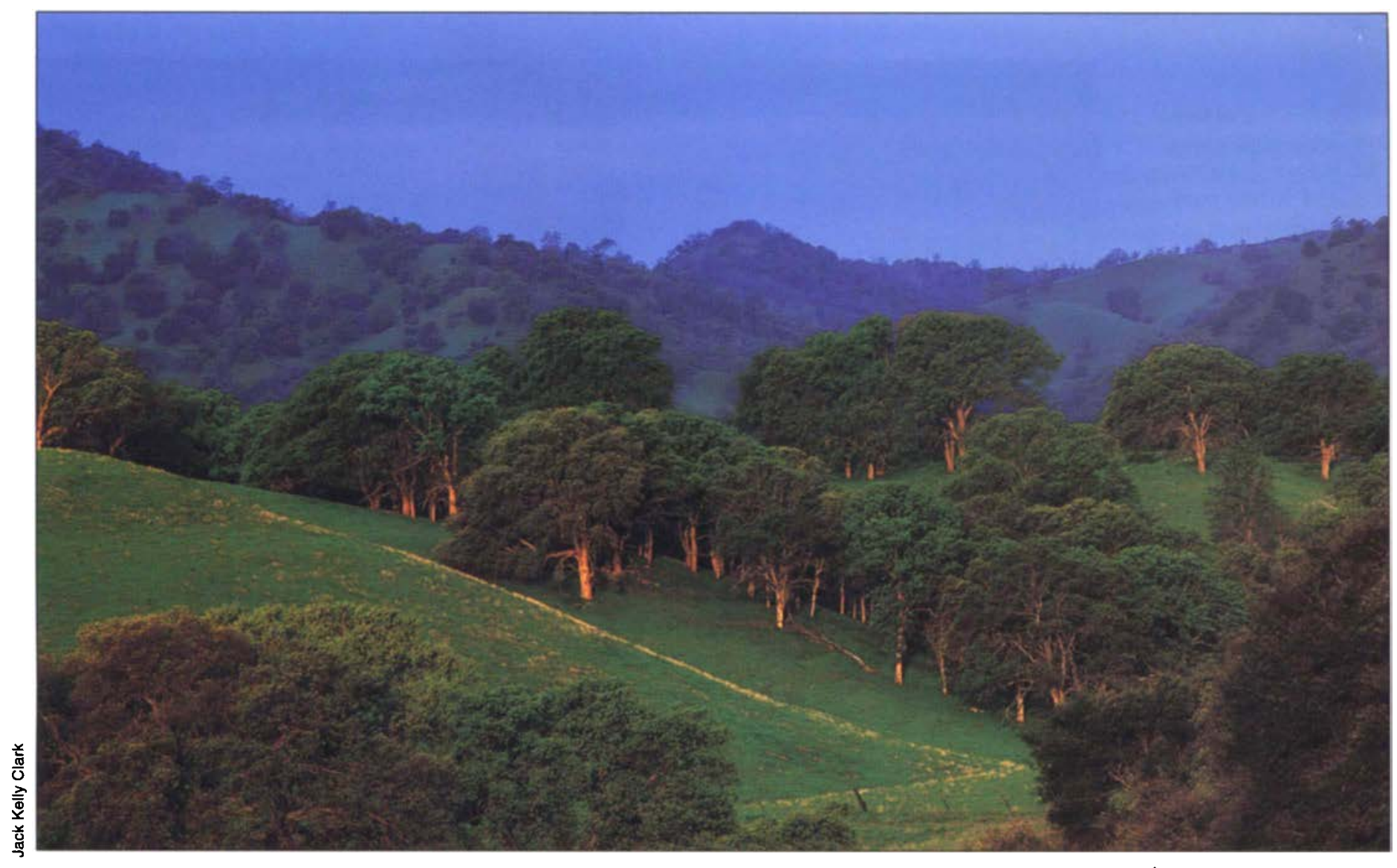

A Blue oak woodland in western Yolo County.

\title{
Weed control improves survival of transplanted blue oak
}

\author{
Theodore E. Adams \\ a Peter \\ B. Sands \\ a William B. McHenry
}

The oak-grassland savanna, with its scattered oaks (Quercus sp.), and the hardwood woodlands that have denser canopies of trees, are distinctive features of California's landscape. These oak woodlands are habitat for a great many wildlife species, and they provide many other benefits important to the human population. Because of the significance of oaks to California, the lack of young trees in many stands is of concern to a wide range of scientists, land managers and conservation groups. The absence of recruitment in some locations, especially in stands of blue oak ( $Q$. douglasii), which represent about $40 \%$ of the oak woodlands, suggests a declining ability of the resource to sustain itself.

During the last decade, many studies have examined problems associ- ated with poor recruitment. Observations to date suggest that competing herbaceous vegetation is one factor that has a strong negative influence on seedling survival and growth, at least in experimental plantings.

To examine the effects of herbaceous vegetation (weed-) control strategies on blue oak seedling survival and growth, we conducted studies at two locations, using 2- to 3-month-old nursery stock. Plantings were made in three successive years at the UC Hopland Research and Extension Center (HREC) in Mendocino County and at the UC Sierra Foothill Research and Extension Center (SFREC) in Yuba County. Results are intended to help in the development of restocking techniques that may be applied where natural replacement is 


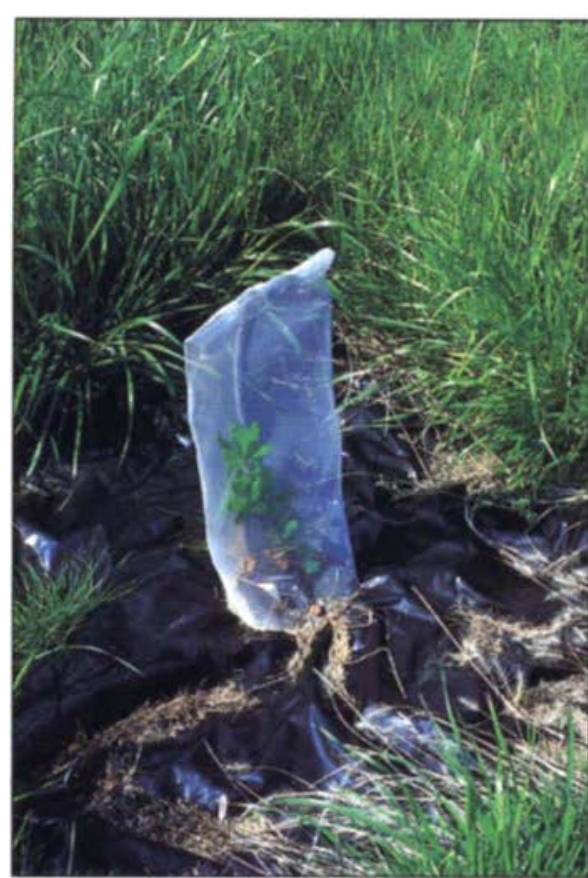

All blue oak seedlings were protected from insects and small mammals by screen cages. An impervious plastic mat suppressed weeds around this seedling.

inadequate and planting is necessary for mitigation.

\section{Weed-control strategies}

The half-acre planting site at each location is typical of local blue oak woodlands on upland soils. Understories are dominated by annual grasses and forbs. Both sites are in open oak woodland, away from canopy influence and on terrain as flat as possible to reduce effects of slope exposure and inclination. The sites are fenced to prevent browsing of seedlings by large herbivores, including cattle, sheep and deer.

At each site, the three successive plantings of 2- to 3-month-old blue oak nursery stock were made early in 1988, 1989 and 1990. These transplants were greenhouse-propagated from acorns collected locally each year in fall. After germination, acorns were planted in 1-inch-square, by 6-inchdeep plastic tubes filled with a standard potting mix. Tubes were placed in boxes 1 foot by 2 feet for handling in the greenhouse and fertilized with a broadcast application of 1 pound of Osmocote 18-6-12 (9-month slow release) for every 12 boxes (approximately 0.005 ounce per tube). When planted in the field, each seedling was

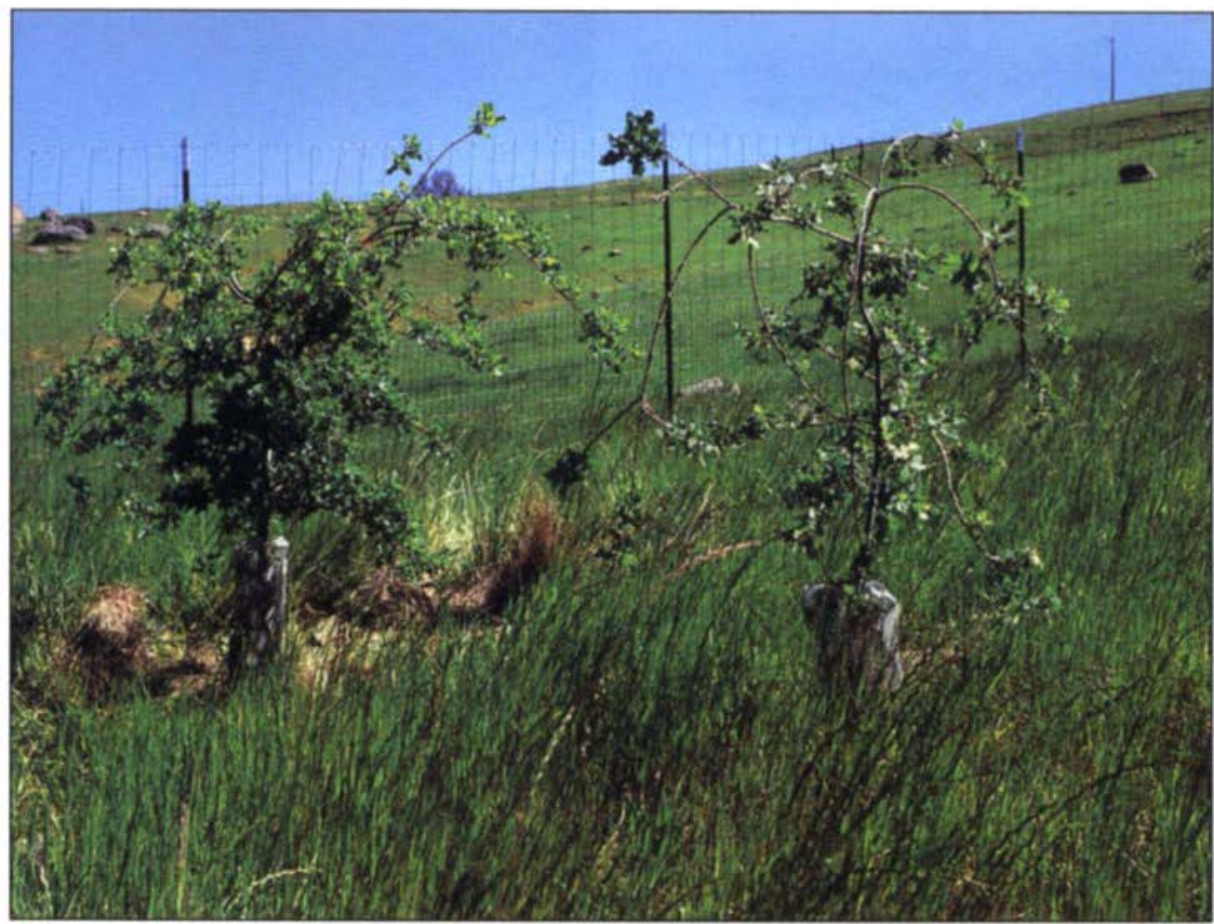

Sierra Foothill Research and Extension Center (SFREC) in Yuba County was one of two sites. Blue oak seedlings protected from weeds by porous plastic mulch mats grew vigorously compared with seedlings treated with soll-active herbicides.

extracted from its tube and placed in a 6-inch-deep hole dug with a power auger. To ensure adequate soil moisture at planting and to settle soil around seedling roots and eliminate air pockets, a quart of water was applied to each seedling after planting.

We evaluated three weed-control strategies: (1) a one-time, postplanting application of soil-active herbicides; (2) porous plastic (PP) mulch mats; and (3) impervious plastic (IP) mats. These were compared with no weed control. Herbicides used in a sprayed mix were atrazine ( 2 pounds per acre) and oxyfluorfen (1 pound per acre). (Transplants required protection from oxyfluorfen during its application.) Duon (Phillips Fibers Corp.), nonwoven black polypropylene, was used in 1988 for the PP mat treatment. In subsequent plantings, a woven black polypropylene mat, Pac-Weave VGC 1510 (Pak Unlimited, Inc.), was substituted for its durability and ease of installation. Four-mil impervious black polyethylene (Dow Chemical Co.) was used for the IP mat treatment. All plastic materials were advertised as UV-stabilized.

The four treatments were each replicated 40 times in a completely randomized design. Annual plantings at the two sites were arranged in blocks of 160 seedlings each ( 10 by 16 ) with replicates (seedlings) planted on 6-foot centers. No preparation of planting spots, such as scalping, was done. After planting, weed-control materials were applied to a 4-foot square surrounding each seedling. The 16square-foot mulch mats were placed over seedlings, with seedlings projecting through an $\mathrm{X}$-shaped slit cut in the center of each mat. Mats applied in 1989 and 1990 were held in place with 10 to 12 inverted U-shaped steel pins. The pins fastening IP mats in place were 2-inch-by-4-inch, lightweight mulch-mat hold-down pins used for holding plastic sheeting to the ground in strawberry production. Pac-Weave mats were held in place with 1-inchby-6-inch 9-gauge staples. Pins were placed at each corner with one between each corner pin and two to four near the seedling to close the center slit. Because pins could not be forced through the polypropylene mats used in 1988, soil was placed around the perimeter of each mat to hold it in place close to the soil surface. Where herbicides were used, seedlings were individually covered with glass jars during application. 
observations at SFREC suggested a similar impact. Of rodent-caused mortality at HREC, meadow voles were responsible for about two-thirds. This was assessed based on the presence of their unique burrows and surface foraging paths. The remainder, or about one-quarter of all mortality, was attributed to gophers. Damage was greatest among the youngest seedlings, those planted in 1990.

In the 1990 plantings, there was a $24 \%$ decline overall in the number of live seedlings between spring survival measurements made in 1991 and 1992. In these plantings, 1992 survival in the IP mat treatment was less compared with the other weed-control strategies. The difference was moderately significant $(P \leq 0.10)$. Average losses in the older plantings during the period were $11 \%$ and $3 \%$, respectively, for 1989 and 1988 plantings.

Significant declines in annual survival were not recorded after the second or third growing season in any planting, and with one exception, survival in the PP mat treatment showed no significant decline after the first season. At HREC, PP-mat-treatment survival in the 1990 planting continued to decline significantly through the second growing season. Significant differences in survival recorded in 1995 are the result of small annual losses accumulating at different levels of survival.

At SFREC, there was no difference in average height between 1989 and 1990 plantings (table 2). March rainfall in 1990 may be an explanation. Precipitation at this time was $80 \%$ greater than expected at SFREC. This may have encouraged first-season growth that eliminated the usual differential.

Seedling growth was greater at SFREC (table 2). In 1995, average seedling height in the 1989 and 1990 plantings at this site was $40 \%$ greater than at HREC, 42 inches versus 26 inches. At both sites, only synthetic mulch mats consistently encouraged more growth, $30 \%$, compared with no weed control (table 2). Survival in 1988 plantings was inadequate to provide reliable estimates of height.

On average, height of seedlings growing with IP-mat weed control was $7 \%$ greater than that of seedlings growing with PP mats, and the average height of the latter was over 15\% greater than that of seedlings growing with a one-time application of herbicides. These differences were significant. Also significantly different was the average height of seedlings growing in the herbicide treatment compared with that of seedlings growing with no weed control. The former was nearly $15 \%$ greater (table 2 ).

\section{Rodents confound performance}

Rodents had a confounding effect on performance in the 1990 plantings. Survival in the IP mat treatment was particularly affected; the environment beneath the mats appeared to attract voles. However, this did not interfere with the efficacy of the treatment compared with no weed control.

A contributing factor to rodent damage in this study was the absence of all weed control (except for applied weed-control strategies) in the halfacre enclosures. The accumulation of biomass, primarily dead annual grass, apparently created habitat attractive to rodents, particularly voles.

The concentration of nursery stock in this study may also have contributed to rodent herbivory. Seedlings planted in patterns approximating the more random, natural distribution of oak trees may be less vulnerable to both aboveground and belowground attack.

Grasshoppers, also a problem, were especially abundant in 1990 at SFREC. For this reason, the opening of many screens to allow undistorted stem growth was delayed. Screened seedlings earlier exposed were attacked, and many were defoliated. We suspect that the accumulation of biomass provided attractive habitat that helped to concentrate the insects, and their presence probably influenced survival in all plantings at both sites.

\section{Weed control helps}

Compared to HREC, height at SFREC, the drier site, was more than $20 \%$ greater for seedlings with no weed control and nearly $40 \%$ greater for the average among weed-control treatments. These differences occurred even though average annual rainfall at HREC is one-third more than at SFREC (37 inches vs. 28 inches). In research conducted by others using blue oak plant material from both locations planted together at each site, consistent differences in growth and other parameters between the two groups of seedlings were observed. These differences in performance suggested that

\begin{tabular}{|c|c|c|c|c|}
\hline \multirow[b]{3}{*}{$\begin{array}{l}\text { Planting } \\
\text { year }\end{array}$} & \multicolumn{4}{|c|}{ HREC and SFREC combined survival through 1994} \\
\hline & \multicolumn{4}{|c|}{ Treatment } \\
\hline & $\begin{array}{l}\text { No weed } \\
\text { Control }\end{array}$ & Herbicides & $\begin{array}{c}\text { Porous plastic } \\
\text { mats }\end{array}$ & $\begin{array}{l}\text { Impervious plastic } \\
\text { mats }\end{array}$ \\
\hline 1988 & $1 \mathrm{~b}^{*}$ & $9 \mathrm{~b}$ & $15 \mathrm{a}$ & $14 \mathrm{a}$ \\
\hline 1989 & $16 \mathrm{c}$ & $54 \mathrm{~b}$ & $66 \mathrm{a}$ & $62 \mathrm{a}$ \\
\hline 1990 & $19 \mathrm{c}$ & $45 \mathrm{ab}$ & $58 \mathrm{a}$ & $40 \mathrm{~b}$ \\
\hline
\end{tabular}

"Values for each planting not followed by the same letter are different ( $\mathrm{P} \leq 0.05)$ by chi-square analysis.

TABLE 2. Average 1994 fall height of blue oak seedlings developing from 2 to-3-month-old nursery stock planted with 3 weed-control strategies and no weed control at the UC Hopland and Sierra Foothill Research and Extension Centers, in 1989 and 1990

\begin{tabular}{|c|c|c|c|c|}
\hline \multirow[b]{2}{*}{$\begin{array}{l}\text { Planting } \\
\text { year }\end{array}$} & \multicolumn{4}{|c|}{ Treatment } \\
\hline & $\begin{array}{l}\text { No weed } \\
\text { control }\end{array}$ & Herbicides & $\begin{array}{l}\text { Porous plastic } \\
\text { mats }\end{array}$ & $\begin{array}{l}\text { Impervious plastic } \\
\text { mats }\end{array}$ \\
\hline \multicolumn{5}{|l|}{ HREC } \\
\hline 1989 & $25 b^{*}$ & $27 b$ & $32 a b$ & 37 a \\
\hline 1990 & $-t$ & 22 a & $22 a$ & 27 a \\
\hline \multicolumn{5}{|l|}{ SFREC } \\
\hline 1989 & $32 \mathrm{c}$ & $40 \mathrm{bc}$ & $46 a b$ & $49 a$ \\
\hline 1990 & $33 \mathrm{c}$ & 42 bc & $50 \mathrm{a}$ & $49 a b$ \\
\hline
\end{tabular}

"Values for each planting not followed by the same letter are different ( $\leq 0.05)$ by LSD separation. $\dagger$ Too few seedlings survived to provide a reliable estimate of height. 
blue oak from each location represents a distinct geographic race.

The greater height of seedlings observed in the IP mat strategy may be a product of both effective weed suppression over time and the influence of IP mats on the soil environment. The heat absorbed by the impervious black mats could contribute to soil heating, and the mats, acting as insulation, would reduce loss of soil heat. The net effect could encourage growth during cool periods of the season when seedlings not so treated grow more slowly.

From the results of this study, no one strategy can be identified as having a clear advantage over the others with respect to promoting survival. But in two out of the three sets of annual plantings, synthetic mulch mats were superior to the one-time, postplanting application of soil-active herbicides. Based on our experience, caution is suggested in the use of impervious polyethylene (the IP mats) where periodic explosions in the population of meadow voles may occur.

The progression in height among treatments, starting with the shortest (no weed control) and ending with the tallest (IP mats), suggests the value of continuous weed control for promotion of growth. Mats were more effective than the one-time application of soil-active herbicides. Qualitative observations suggested some residual herbicidal effect on weeds beyond the planting season, but this soon disappeared. Both growth and survival emphasize the critical nature of weed control in the first season.

When nursery stock is used for restoration and mitigation, a one-time application of soil-active herbicides for weed control immediately following planting can be both effective and more economically attractive than use of synthetic mulch mats. At a few cents per seedling, use of herbicides in this study was less expensive than installation of plastic mats.

\section{Treatment costs}

Cost of materials for each treatment was highly variable. When the study was initiated, the cost of herbicide spray was less than $\$ 0.02$ per treated seedling, and application time was, perhaps, 10 to 15 seconds per seedling. Mats of Phillips Duon, used the first year as the PP mat treatment, were $\$ 1.41$ each. Adding the cost for $10 \mathrm{~min}$ utes of labor to apply a mat (about $\$ 0.60$ in this study), the expense for each seedling was about $\$ 2$.

For the 1989 and 1990 plantings, the price for each Pac-Weave mat, cut to size by the supplier with a slit for the seedling, was $\$ 1.27$. Purchased in quantity, the hold-down pins used for this material cost $\$ 0.37$ to $\$ 0.42$ per mat. Labor for installation of each mat was, again, about 10 minutes. Installed, each Pac-Weave mat cost about \$2.30.

The less-expensive impervious polyethylene mats cut from bulk rolls were about $\$ 0.60$ each, including cutting to size with a slit for the seedling. Adding installation time (about 10 minutes) and the cost of hold-down pins ( $\$ 0.015$ each, purchased in bulk), treatment using these mats was less than $\$ 1.40$ per seedling.

Screen cages for protection against herbivory were an added cost. This was uniform, about $\$ 0.95$ for each seedling, including labor.

\section{Conclusions}

Weed competition can severely limit survival of out-planted blue oak seedlings developing from 2- to 3month-old nursery stock. Competition may be one of the most important obstacles to oak recruitment; it may be necessary to maintain new plantings weed-free for at least the first growing season. But it is not clear that active control beyond the planting season significantly improves survival, although it does improve growth.

Efficacy, cost, ease of application and other considerations enter into the selection of a weed-control strategy. Choice may be influenced by the effect the strategy has on other mortality factors. Our experience suggests that impervious black polyethylene mats can create attractive habitat for meadow voles around oak seedlings and encourage the rodents' depredations. We did not identify a superior method of control, but use of herbicides was by far the least expensive and easiest to apply.
An important consideration is the potential for herbivory. Large herbivores, such as deer and livestock, are a recognized problem. But small mammals, including meadow voles and pocket gophers, are also threats, as are insects, especially grasshoppers. Full to partial protection of oak seedlings with fences and screen cages may be necessary for several seasons, at least until the plants are big enough to withstand attack. Herbivory can be as critical a factor as weed competition, and protection, as well as control of weeds, may be necessary to ensure success of restocking and mitigation programs.

\section{Update}

In spring 1997, survival in the 1989 and 1990 plantings at SFREC was reexamined. Without regard to planting date, we recorded survival in the four treatments and noted the number of seedlings attacked by gophers in 1997 but recovering (new sprouts present). In the IP mat treatment, $42 \%$ of the seedlings had been attacked, whereas $26 \%$ was the average attacked for all other treatments. The difference was moderately significant $(P \leq 0.10)$. Conditions beneath mats, the condition of seedlings growing with IP mat weed control or a combination of these or other associated factors may be responsible for the difference. But again, a caution in the use of impervious black polyethylene for weed control is suggested.

T.E. Adams is Extension Wildlands Specialist and P.B. Sands is Staff Research Associate (retired), Department of Agronomy and Range Science, UC Davis; and W.B. McHenry is Extension Weed Scientist, Emeritus, Department of Vegetable Crops, UC Davis.

Partial support for this research was provided by the UC Integrated Pest Management Project; the UC Integrated Hardwood Range Management Program; the Napa Nursery, California Conservation Corps; UC Hopland (HREC Grant No. 35-84) and Sierra Foothill (SFREC Grant No. 039) Research and Extension Centers; The Dow Chemical Co.; and International Reforestation Supply, Eugene, Ore. 